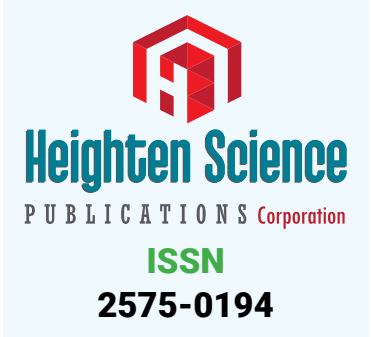

*Address for Correspondence: Dr. B Kavitha, Ph.D, Department of Food Science and Nutrition, Nammalavar Agricultural College and Technology, Affiliated by Tamil Nadu Agricultural University, Coimbatore, India, Tel: +91 9944241416; Email: kavitharamesh82@gmail.com

*Sugasini Dhavamani, University of Illinois, USA, Email: dhavamsuga@gmail.com

Submitted: 27 February 2018

Approved: 09 March 2018

Published: 12 March 2018

Copyright: @ 2018 Kavitha B, et al. This is an open access article distributed under the Creative Commons Attribution License, which permits unrestricted use, distribution, and reproduction in any medium, provided the original work is properly cited.

Keywords: Black gram varieties; Physicochemical parameters; Texture Microstructure; Thick pancake (Dosa)

\section{Nutritional and structural evaluation of selected Black gram varieties for preparation of Fermented Thick Pancake (Dosa)}

\author{
Kavitha B ${ }^{1 *}$, Sugasini ${ }^{2 *}$, Poorna CR Yalagala ${ }^{2}$, Hemalatha $C^{1}$, \\ Kanchana $\mathrm{S}^{1}$, Meenakshi $\mathrm{V}^{3}$ and Umamaheswari $\mathrm{R}^{3}$ \\ 'Department of Food Science and Nutrition, Nammalavar Agricultural College and Technology, \\ Agricultural University, Tamilnadu, India \\ ${ }^{2}$ Department of Endocrinology, Illinois University, USA \\ ${ }^{3}$ Department of Food Science and Nutrition, Home Science College and Research Institute, \\ Agricultural University, Tamilnadu, India
}

\section{Abstract}

The quality characteristics of selected black gram varieties viz., VBN 5, VBN 7, ADT 3, T9 and $C 06$ and were evaluated for their suitability for the preparation of thick pancake. The foaming stability and foaming capacity were found to be maximum in VBN 5, CO 6 and T9. Maximum rise in volume was recorded in CO 6 (149 ml) followed by VBN $5(148 \mathrm{ml})$ and T9 $(147 \mathrm{ml})$ which is an indication good quality of thick pancake. Thick pancake prepared using 5 black gram varieties were analyzed for the physicochemical and microbial load. The texture profile viz., springiness, cohesiveness, chewiness and gumminess was evaluated for VBN 5, CO 6, T9 and VBN 7 respectively. The protein content was higher in thick pancake prepared from VBN $5(25.47 / 100 \mathrm{~g})$ compared to $\mathrm{CO} 6(24.66 \mathrm{~g} / 100 \mathrm{~g})$. Among the selected varieties, CO 6, T9 and VBN 5 had good batter content, texture, and microstructure and were found to be most suitable for thick pancake preparation.

\section{Introduction}

Just like a thick pancake (Dosa) is also a favourite fermented food of India, particularly in the South. The batter preparation for a thick pancake (dosa) is similar to that of idli, except the rice and black gram are finely ground, and this pan cake batter is comparatively thinner compared to rice batter. The batter is spread out as a thin, fairly crisp pancake as a greased hot tawa and sparingly sprinkled with oil and cooked crisply on both sides an eaten directly with accompaniments as from idli [1-3]. Instant mixes of traditional products such as idli, dosa and vada based on rice and black gram blend flours are becoming increasingly popular in the Indian market [4-6]. Due to a larger difference in the prices for black gram and other cereals, the manufacturers are tempted to reduce the proportion of black gram in the flour mix while tailoring the texture by use of other processing aids [7].

The pancake is a popular breakfast dish across South Indian homes and a favorite eat-out dish for the rest of India [8]. Quick and easy define it really. Some varieties need no time with the batter; some need a bit of fermentation [6,9]. However, the sum of all products is always the same-tasty dosas. Masala dosa Just plain dosa with a spiced mashed potato filling. Many types of dosa available in the market these are the various types of dosa prepared from black gram such as there are rawa dosa made with semolina and rice flour [10]. No grinding, no fermenting. Just mix the two with water or buttermilk.pesarathu Dosa made of green gram (moong daal). A popular Andhra 
Pradesh breakfast and snack, made by mixing chopped green chillies, ginger and onions to the green gram batter. Neer dosa from Karnataka. "Neer" means water in Kannada. Really thin dosa made of water and rice flour [11-13]. No fermenting. Davangere Benne Dosa from Davangere, a north-west Karnataka town. Means butter dosa. Dosa made with white unsalted butter. There are three kinds of these-Benne Khali dosa, Benne open dosa and Benne masala dosa, depending on whether the potato masala is inside or outside the dosa.Adai dosa-Protein-rich dosa made of different types of pulses (urad daal, chana daal, toor daal, yellow and green mong daal, arhar daal) mixed with cumin and fennel seeds and chopped chillies, onions, ginger and coriander or curry leaves [14-16]. Maida Dosa made of maida (plain flour) and rice flour mixed with chopped chillies, onions, ginger and coriander or curry leaves. No fermenting. Atta dosa made of atta (wheat flour) and rice flour, with or without chopped chillies, onions, ginger and coriander or curry leaves. This paper aims to screen blackgram varieties and to record the quality characteristics of thick Pancake (dosa batter) and to evaluate the textural, nutritional, organoleptic and microbiological characteristics of a thick pancake.

\section{Materials and Methods}

\section{Samples used}

The seeds of black gram variety viz., VBN 3, VBN 4, VBN 5, VBN 6, VBN 7, CO 6, ADT 3, TMV, T9, VBg 010-024, VBg 010-025 and VBg 009-005 were procured from National Pulse Research Institute (Vamban), Agricultural College and Research Institute (Madurai) and Department of Pulses, TNAU (Coimbatore). The seeds of all the varieties were freed from extraneous material and stored in air tight plastic containers under ambient conditions. All other ingredients viz., rice and fenugreek used in the preparation of pan cake batter and pan cake preparation were procured from the local market in Madurai.

\section{Functional and chemical properties of selected black gram varieties}

Twelve black gram varieties were screened based on their functional and chemical properties. Functional characteristics such as foaming capacity (FC) and foaming stability (FS) of black gram were measured by the volumetric method as described by Lin et al. [17]. The arabinose and galactose content of selected black gram varieties were analyzed using High-Performance Liquid Chromatography (HPLC) as given by Tanaka [18]. The fatty acid composition was analyzed by solvent extraction method Cohen [19].

\section{Thick pancake batter preparation}

For estimating the apparent grain volume, $25 \mathrm{~g}$ of split dhal of each variety were measured in a measuring cylinder. The initial batter volume was estimated by measuring the increase in black gram batter in a measuring cylinder, soon after grinding and mixing of rice batter and black gram batter. The final batter volume was estimated by measuring the fermented rice and black gram batter volume after gentle stirring.

\section{Thick pancake preparation}

Milled parboiled rice and dehusked black gram dhal were soaked separately in portable water for 6 to 8 hours. The water is drained, and the soaked rice was ground to a fine gelatinous paste, while thus the drained black gram dhal was ground to a fluffy soft texture. The rice and black gram batter were mixed together, and $0.8 \%$ salt was added, and the thick pancake (Dosa) batter was incubated at room temperature, and the fermentation was allowed to take place for $12 \mathrm{hrs}$. The fermented batter was further mixed well with a stainless steel ladle. The batter was spread out as a thin, fairly crisp thick pancake as a greased hot tawa and sparingly sprinkled with oil and cooked crisply on both sides and eaten directly (Figure 1). 


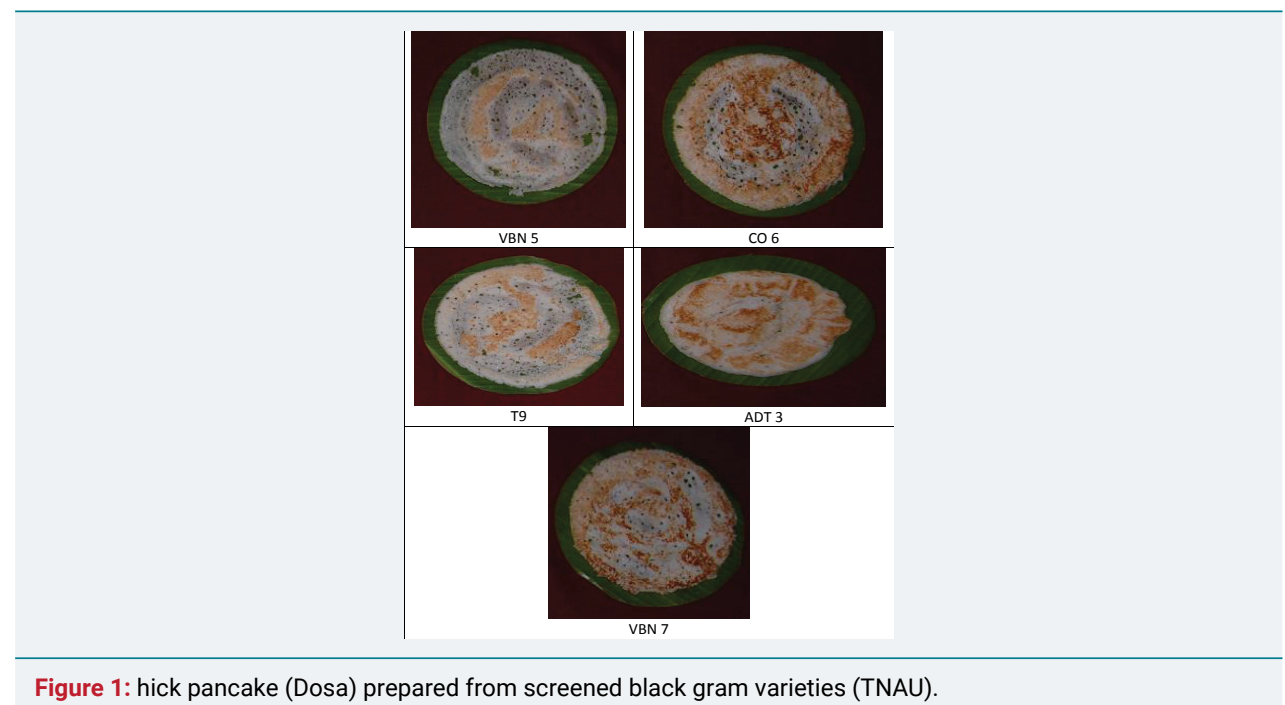

\section{Analysis of thick pancake (Dosa) batter}

Thick pancake (Dosa) batter was studied for batter volume, batter weight, and increase in batter volume as per method is given by Kanchana et al. [20]. Acidity and pH were analysed as per method is given by Saini et al.; Clark et al, [21,22].

\section{Physico-chemical properties and sensory score thick pancake}

The thick pancake samples were analyzed for contents of moisture (AOAC 1995) [23], ash, fat, protein (AOAC 1998) [24], starch (AOAC 2005) [25], calcium, phosphorus and iron were analyzed by dry ashing method (AOAC 2005) [25]. Microbial load of the products were enumerated by Istavankiss [26]. The sensory quality of the product was evaluated using a nine-point hedonic rating scale [27].

\section{Texture and microstructure analysis of thick pancake}

Textural parameters of Thick pancake (Dosa) (VBN5, VBN7, CO 6 and T9) viz., hardness, cohesiveness, adhesiveness, springiness, gumminess and chewiness were studied by using texture analyzer (Model TA-Ti, Stable Microsystems, UK). The microstructure of dosa samples was studied under Microscope (Euromex Cmex 3, Netherlands).

\section{Statistical analysis}

All results of triplicate samples were statistically analyzed using Fisher's least significant differences (LSD) test to differentiate the treatment means and the level of significance $(\mathrm{P}<0.05)$. Statistical analysis was performed by using Statistica Version 5.5 (Statsoft Inc., OK, and the USA) software. In reporting data, the results of individual samples were reported as the mean \pm standard deviation. Factorial Completely Randomized Design (FCRD) as per the method described by Gomez and Gomez [28] was employed for the analysis with a triplicate number of samples.

\section{Results and Discussion}

\section{Functional and chemical properties of selected black gram varieties}

The foaming capacity of the 12 black gram varieties ranged between 33.33 (VBN 7) to 35.71 (VBN 5) g per cent. Foaming stability was maximum for T9 (35.2 g per cent), followed by VBN 5 ( $35.12 \mathrm{~g}$ per cent) and minimum for VBN 4 (32.46 g per cent) after 120 min of storage. The FC and FS have a significant influence on the textural and leavening properties of idli and thick pancake (dosa) [29]. The mucilaginous texture of black gram is attributed to the arabinogalactan, present exclusively in black gram which is also responsible for smooth, spongy texture of idli and thick pancake (dosa). 
The arabinose and galactose content of variety VNB 5 (19.8 and $\left.23.6 \mathrm{mg} \mathrm{g}^{-1}\right)$ were significantly higher followed by T9 (16.9 and $20.1 \mathrm{mg} \mathrm{g}^{-1}$ ). Black gram polysaccharide may be accounted for exerting higher foaming stability $[29,30]$. Based on the functional and chemical properties, five black gram varieties viz., VBN 5, T9, ADT 3, CO 6 and VBN 7 were screened and used for the preparation of South Indian breakfast thick pancake dosa. The study results were given for thick pancake (dosa) batter and thick pan cake (dosa).

\section{Analysis of thick pancake batter}

The prepared thick pancake batter was studied for physicochemical characteristics. Batter quality analysis such as batter weight (g), batter volume (ml), raise in batter volume ( $\mathrm{ml}), \mathrm{pH}$ and acidity were analyzed from the selected black gram varieties.The black gram varieties viz., VBN 5, T9, ADT 3, CO 6 and VBN 7 were found to have good acceptability for thick pancake development. The batter was prepared from rice and black gram as for thick pancake preparation, and the physicochemical parameters of the batter were evaluated.The physicochemical analyses of thick pancake batter prepared using the selected 5 black gram varieties were assessed for the results are given in table 1 . The batter weight reduced gradually during a fermentation period of 18 hours and ranged between 272 and $318 \mathrm{~g}$, and batter volume increased almost two-fold in all the varieties just as for thick pancake batter. The increase in volume ranged between 147 and $149 \mathrm{ml}$ for the batter prepared from $100 \mathrm{~g}$ of rice and $30 \mathrm{~g}$ of black gram. Maximum rise in volume was found in black gram varieties CO $6(149 \mathrm{ml})$ followed by VBN $5(148 \mathrm{ml})$, T9 $(147 \mathrm{ml})$, VBN $7(147 \mathrm{ml})$ and ADT $3(110 \mathrm{ml})$. The rise in volume is an indication of the good quality of batter which is highly suited for thick pancake preparation. The changes in $\mathrm{pH}$ and acidity brought about by batter fermentation were evaluated. The $\mathrm{pH}$ of the batter ranged 6.18 to 6.20 , and after fermentation for 18 hours, the corresponding value ranged from 4.28 to 4.51 . The changes in $\mathrm{pH}$ are attributed to the concomitant increase in acidity during fermentation which had increased from an initial level of 0.07 to $0.44 \mathrm{~g} / 100 \mathrm{~g}$ after 18 hours of fermentation.

\section{Physico-chemical properties and sensory score of thick pancake}

The data about physical characteristics such as diameter and texture were analyzed thick pancake prepared from selected black gram varieties. The diameter of thick pancake developed from the different black gram varieties ranged from 8.00 to $8.50 \mathrm{~cm}$ (Table 2). The texture of dosa was assessed regarding the number of pores measured by the ink print test method, where in the applied prints furnish a record

\begin{tabular}{|c|c|c|c|c|c|c|c|c|c|}
\hline \multirow{2}{*}{ Varieties } & \multicolumn{2}{|c|}{ Batter weight (g) } & \multicolumn{2}{|c|}{ Batter volume $(\mathrm{ml})$} & \multirow{2}{*}{$\begin{array}{l}\text { Increase in batter volume } \\
\qquad(\mathrm{ml})\end{array}$} & \multicolumn{2}{|c|}{ pH } & \multicolumn{2}{|c|}{ Acidity $(\mathrm{g} / \mathbf{1 0 0 g})$} \\
\hline & Initial & Final & Initial & Final & & Initial & Final & Initial & Final \\
\hline T9 & 319 & 318 & 86 & 232 & 147 & 6.20 & 4.51 & 0.0756 & 0.4430 \\
\hline VBN 5 & 333 & 331 & 90 & 240 & 148 & 6.18 & 4.52 & 0.0755 & 0.4445 \\
\hline $\mathrm{CO} 6$ & 316 & 315 & 88 & 237 & 149 & 6.18 & 4.35 & 0.0723 & 0.4420 \\
\hline ADT 3 & 320 & 314 & 95 & 205 & 110 & 6.18 & 4.28 & 0.0712 & 0.4406 \\
\hline VBN 7 & 274 & 272 & 85 & 232 & 147 & 6.20 & 4.43 & 0.0716 & 0.4410 \\
\hline SED & \multicolumn{2}{|c|}{0.1208} & \multicolumn{2}{|c|}{0.1483} & 0.1245 & \multicolumn{2}{|c|}{0.2141} & \multicolumn{2}{|c|}{0.3342} \\
\hline$C D(P<0.01)$ & \multicolumn{2}{|c|}{$0.2452^{\star \star}$} & \multicolumn{2}{|c|}{0.3361 ** } & $0.4631 * \star$ & \multicolumn{2}{|c|}{$0.3772^{\star \star}$} & \multicolumn{2}{|c|}{$0.5682^{*}$} \\
\hline
\end{tabular}

Table 2: Physical characteristics of thick pancake (Dosa).

\begin{tabular}{|c|c|c|}
\hline Varieties & Diameter $(\mathbf{c m})$ & Number of pores (Per square inch) \\
\hline VBN 5 & 8.50 & 14 \\
\hline T9 & 8.15 & 13 \\
\hline ADT 3 & 8.10 & 11 \\
\hline CO 6 & 8.20 & 12 \\
\hline VBN 7 & 8.00 & 10 \\
\hline SED & 0.0212 & 0.0297 \\
\hline CD(P<0.01) & $0.4522^{\star \star}$ & $0.4628^{\star}$ \\
\hline
\end{tabular}


of the number of pores per square inch in the graph sheets. The texture of the dosa was evaluated by observing the porosity, which indicates the softness of the developed dosa. Among the selected varieties VBN 5, T9, CO 6 and ADT 3 showed maximum pores of $14,13,12$ and 11 respectively. The higher number of pores in a thick pancake is an indication of the soft texture of idli. Hence the varieties mentioned above were selected for development of thick pancake.

\section{Chemical characteristics of thick pancake}

The prepared thick pancake was studied for chemical characteristics such as moisture, protein, ash, fat, starch and organoleptic evaluation from the selected black gram varieties. The chemical composition was given in table 3 . Higher moisture content was found in VBN 5 (35.11 g/100g) and CO 6 (33.20 g/100g). The moisture content was highest in the thick pancake sample prepared from VBN 5 indicating moisture and soft texture which is a desired sensory attribute for optimum thick pancake quality. The maximum value for ash content was noted in ADT $3(9.20 \mathrm{~g} / 100 \mathrm{~g})$ followed by VBN $5(9.10 \mathrm{~g} / 100 \mathrm{~g})$, CO 6 (8.20 g/100g), T9 $(8.30 \mathrm{~g} / 100 \mathrm{~g})$ and VBN $7(8.00 \mathrm{~g} / 100 \mathrm{~g})$. The fat content of the thick pancake sample ranged from 2.10 to $2.50 \mathrm{~g} / 100 \mathrm{~g}$ with minimum, and maximum values noticed in the thick pancake prepared from varieties VBN 5 and VBN 7 respectively. Thick pancake prepared from variety T9 and ADT 3 had a fat content of $2.12 \mathrm{~g}$ to $2.50 \mathrm{~g} / 100 \mathrm{~g}$. Higher protein content was observed in ADT 3 and CO 6 variety thick pancake with the values of 24.47 and $25.66 \mathrm{~g} / 100 \mathrm{~g}$. Significant variation was observed for protein content among the thick pancake samples. The thick pancake prepared from varieties VBN 7, VBN 5, CO 6, ADT 3 and T9 had starch content of $26.00,29.39,32.83,32.00$ and $28.00 \mathrm{~g} / 100 \mathrm{~g}$ respectively. A significant difference was observed for starch content among the thick pancake samples prepared from the different varieties.

The data about the calcium and iron content in variety VBN 7 was 24.00 and 5.10 $\mathrm{mg} / 100 \mathrm{~g}$ respectively. The calcium content for the other thick pancake samples prepared from varieties CO 6, ADT 3, T9, VBN 5 and VBN 7 was 28.15, 22.46, 25.00, 23.51 and $24.00 \mathrm{mg} / 100 \mathrm{~g}$ respectively and the corresponding values for iron content were $5.30,5.25,5.40,5.5$ and $5.25 \mathrm{mg} / 100 \mathrm{~g}$ respectively. Statistical analysis revealed the highly significant difference between all the dosa samples. Nazini and Shalini [31] reported that on a comparison of the calcium, iron and protein content was found to be maximum in pearl millet idli $(41.44,4.7 \mathrm{mg} / 100 \mathrm{~g}$ and $9.16 \mathrm{~g} / 100 \mathrm{~g})$ followed by multi grain idli $(30.48,2.43 \mathrm{mg} / 100 \mathrm{~g}$ and $9.10 \mathrm{~g} / 100 \mathrm{~g})$ and control idli $(26.76,1.16$ $\mathrm{mg} / 100 \mathrm{~g}$ and $7.28 \mathrm{~g} / 100 \mathrm{~g}$ ) [32] assessed the chemical characteristics of sorghum and moth bean incorporated idli and dosa at 50 per cent level. The moisture, protein, ash and fat content were observed as $32.70,25.6,8.20$ and $1.65 \mathrm{~g} / 100 \mathrm{~g}$.

\section{Organoleptic evaluation of thick pancake}

Organoleptic quality of thick pancake was evaluated by 30 semi-trained judges using 9 points hedonic scale rating, and the sensory scores are given in table 4 . The quality attributes were assessed for colour, flavour, texture, taste and overall acceptability. Concerning colour, flavour and texture, the score value was higher for VBN 5, CO 6 and T9. The score for taste and overall acceptability ranged between 9.0, 9.0 and 8.8.

Table 3: Chemical characteristics of thick pancake (dosa).

\begin{tabular}{|c|c|c|c|c|c|c|c|}
\hline Parameters & VBN 5 & T9 & ADT 3 & CO 6 & VBN 7 & SED & CD (0.01) \\
\hline Moisture (g/100g) & 35.11 & 32.50 & 32.00 & 33.20 & 30.00 & 0.3241 & $0.4269^{\star \star}$ \\
\hline Ash $(\mathrm{g} / 100 \mathrm{~g})$ & 9.10 & 8.30 & 9.2 & 8.20 & 8.0 & 0.3221 & $0.4337 \mathrm{NS}$ \\
\hline Fat $(\mathrm{g} / 100 \mathrm{~g})$ & 2.10 & 2.12 & 2.50 & 2.14 & 2.60 & 0.0225 & $0.2084^{\star}$ \\
\hline Protein $(\mathrm{g} / 100 \mathrm{~g})$ & 24.22 & 22.49 & 24.47 & 25.66 & 22.00 & 0.6826 & $0.7425^{\star}$ \\
\hline Starch $(\mathrm{g} / 100 \mathrm{~g})$ & 29.39 & 28.00 & 32.00 & 32.83 & 26.00 & 0.7768 & $0.7823^{\star \star}$ \\
\hline Calcium $(\mathrm{mg} / 100 \mathrm{~g})$ & 23.51 & 25.00 & 22.46 & 28.15 & 24.00 & 0.6752 & $0.6723^{\star \star}$ \\
\hline Iron $(\mathrm{mg} / 100 \mathrm{~g})$ & 5.5 & 5.4 & 5.25 & 5.3 & 5.10 & 0.4060 & $0.5960^{\star \star}$ \\
\hline
\end{tabular}




\begin{tabular}{|c|c|c|c|c|c|c|}
\hline \multicolumn{7}{|l|}{ Table 4: Mean score value of organoleptic characteristics of thick pancake (dosa). } \\
\hline Parameters & VBN 5 & T9 & ADT 3 & C0 6 & VBN 7 \\
\hline Appearance and Colour & 9.0 & 8.9 & 9.0 & 9.0 & 8.6 \\
\hline Flavour & 8.8 & 8.8 & 8.5 & 8.9 & 8.3 \\
\hline Texture & 8.9 & 8.9 & 8.5 & 8.8 & 8.4 \\
\hline Taste & 8.9 & 8.8 & 8.8 & 9.0 & 8.4 \\
\hline Over all acceptability & 8.8 & 8.9 & 8.7 & 9.0 & 8.5 \\
\hline
\end{tabular}

The thick pancake (Dosa) samples prepared from black gram varieties VBN 5, CO 6 and T9, were found to have good organoleptic characteristics. Poongodi Vijaya Kumar [33] reported that the softness of dosa from composite flour was marginally less in comparison with the softness of dosa from rice flour. The softness of dosa from $30 \%$ MBCF was just about right and others in most of the liking score on softness and also good sensory profile.

\section{Texture Profile Analysis (TPA) and microstructure of thick pancake (Dosa) from best variety}

Based on physicochemical properties and sensory evaluation, VBN 5, CO 6 and T9 were found to have maximum acceptability. Hence, texture profile and microstructure of prepared from these two varieties along with a control variety (VBN 7) were analyzed. The texture values of thick pancake (Dosa) are given in table 5. The springiness values of the thick pancake (Dosa) samples prepared from varieties, T9, VBN 5, CO 6 and VBN 7 was $1.044 \mathrm{~mm}, 1.357 \mathrm{~mm}, 1.258 \mathrm{~mm}$ and $1.024 \mathrm{~mm}$ respectively. The springiness of thick pancake (Dosa) prepared from VBN 5, CO 6 and T9 varieties were higher when compared to VBN 7 thick pancake (Dosa). Higher springiness value was found in the thick pancake (Dosa) samples prepared from VBN $5(1.357 \mathrm{~mm})$ which was found to be statistically significant $(\mathrm{p}<0.05)$ compared to the springiness values of the thick pancake (Dosa) prepared from other black gram varieties. Cohesiveness was maximum for VBN $5(0.440 \mathrm{~mm})$ than VBN 7, CO 6 and T9 which was $0.400,0.430$ and $0.420 \mathrm{~mm}$ respectively. Chewiness was maximum in T9 $(2.994 \mathrm{~mm})$ compared to 2.351, 2.370 and $1.753 \mathrm{~mm}$ in variety VBN 5, CO 6 and VBN 7 respectively. The highest value for gumminess was observed in T9 $(2.892 \mathrm{~mm})$ followed by VBN 5 $(2.105 \mathrm{~mm})$, CO $6(2.101 \mathrm{~mm})$ and VBN $7(1.581 \mathrm{~mm})$. A significant difference $(\mathrm{p}<0.05)$ was observed for cohesiveness, gumminess and chewiness of the thick pancake (Dosa) prepared from the different black gram varieties for VBN 5 incorporated thick pancake (Dosa). Springiness i.e., the ability to retain shape and attain the original values after withdrawal of pressure force was maximum for VBN $5(1.357 \mathrm{~mm})$ which also had the highest cohesiveness $(0.440 \mathrm{~mm})$. So also the chewiness and gumminess were moderate for a thick pancake (Dosa) prepared from VBN $5(2.105 \mathrm{~mm})$ compared to 1.581 and $2.892 \mathrm{~mm}$ obtained for VBN 7 and T9. This indicated that VBN 5 and CO 6 was most suitable thick pancake (Dosa) making compared to VBN 7 and T9. Tharnathan and Mahadevamma [34] reported that the fluffiness and sponginess of idli were increased with increase in the proportion of black gram dhal and fermentation time. The maximum score for fluffiness was 11.4 for the idli made with cereal: pulse combination of $3: 2$ at 12 hours fermentation time, so this same idli batter was used for dosa preparation, so this results also support my studies of a different variety of thick pancake (Dosa) preparation. Poongodi Vijayakumar [33] and Sanz-Serrano et al. [35] stated that the dosa from $30 \%$ Millet based composite flour was less cohesive than dosa from other composite flour and rice flour.

\section{Microstructure}

The microstructure of the dosa prepared from varieties VBN 5, T9, CO 6 and ADT 3 was analysed by cutting the thick pancake (Dosa) conforming to $1 \mathrm{x} 1 \mathrm{~cm}$ regarding width and breadth. The cut halves were then subjected to the cross-sectional view under a microscope, and the results are shown in figure 2. Microstructure profile reveals the linear profile of leavening of the batter and incorporation of air and porosity of the 


\begin{tabular}{|c|c|c|c|c|}
\hline \multicolumn{4}{|c|}{ Table 5: Texture profile analysis of thick pancake (dosa) prepared from selected black gram varieties. } \\
\hline Varieties & Springiness $(\mathbf{m m})$ & Cohesiveness $(\mathbf{m m})$ & Chewiness $(\mathbf{m m})$ & Gumminess $(\mathbf{m m})$ \\
\hline VBN 7 & $1.024^{\mathrm{a}}$ & $0.420^{\mathrm{a}}$ & $1.753^{\mathrm{a}}$ & $1.581^{\mathrm{a}}$ \\
\hline VBN 5 & $1.357^{\mathrm{a}}$ & $0.440^{\mathrm{b}}$ & $2.351^{\mathrm{b}}$ & $2.105^{\mathrm{b}}$ \\
\hline T9 & $1.044^{\mathrm{b}}$ & $0.400^{\mathrm{a}}$ & $2.994^{\mathrm{c}}$ & $2.892^{\mathrm{c}}$ \\
\hline CO 6 & $1.258^{\mathrm{a}}$ & $0.430^{\mathrm{b}}$ & $2.370^{\mathrm{b}}$ & $2.101^{\mathrm{b}}$ \\
\hline
\end{tabular}

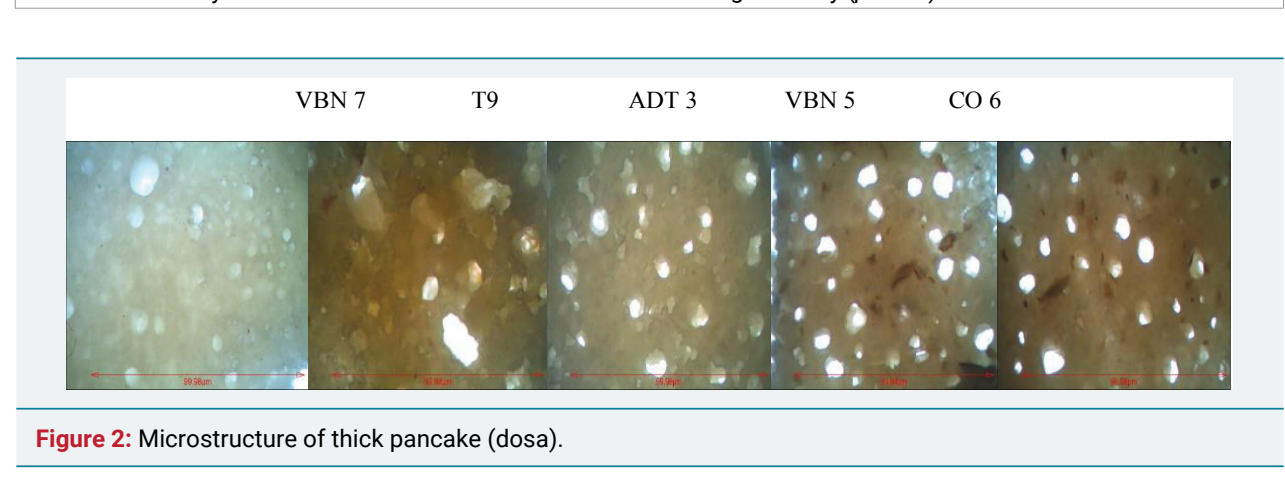

product. Higher the numbers of pores were found to correlate to better batter quality, foaming capacity and the content of the mucilaginous substance arabinogalactan in the black gram variety. The texture and softness level was higher in thick pancake (Dosa) developed from VBN 5 and T9 varieties compared to VBN 7. Kanchana et al. [20] and Lu et al. [36] studied the microstructure rupture of idli and dosa from selected rice and pulse varieties. The texture was found to be very soft and more pores were present in idli and dosa prepared from rice variety(Ambai16, Ambai36, ASD19, CR1009) and black gram variety CO 6 and T9. Similar observations seen in the present study with variety CO 6 and T9 which exhibited good thick pancake (Dosa) making quality on par with variety VBN 5.

\section{Conclusion}

In this study, VBN 5, CO 6 and T9 were found to be better for thick pancake (Dosa) preparation. The best varieties contain a higher amount of arabinogalactan and mucilaginous content. Due to higher batter quality and good foaming stability, the textural properties of thick pancake (Dosa) was soft and good in nature in VBN 5, CO 6 and T9 varieties. Thick pancake (Dosa) prepared were found to be as organoleptically and nutritionally superior regarding protein, starch, fat, and mineral contents.

\section{References}

1. Chelliah R, Ramakrishnan SR, Premkumar D, Antony U. Accelerated fermentation of Idli batter using Eleusine coracana and Pennisetum glaucum. J Food Sci Technol. 2017; 54: 2626-2637. Ref.: https://goo.gl/K4mA9W

2. Ohariya P, Singh A, Rajput LPS. Quality attributes of instant kodo-soy idli mix as affected by fermentation period. IJCS; 2017; 5: 1611-1615. Ref.: https://goo.gl/RE98Ym

3. Balasubramanian S, Jincy MG, Ramanathan M, Chandra P, Deshpande SD. Studies on millet idli batter and its quality evaluation. Ifrj. 2015; 22: 139-142. Ref.: https://goo.gl/2Utcrs

4. Sozer N, Holopainen-Mantila U, Poutanen K. Traditional and New Food Uses of Pulses. Cereal Chemistry 2017; 94: 66-73. Ref.: https://goo.gl/k9BtHF

5. Adebo OA, Njobeh PB, Adebiyi JA, Gbashi S, Phoku JZ, et al. Fermented Pulse-Based Food Products in Developing Nations as Functional Foods and Ingredients. InTech. 2018. Ref.:Ref.: https://goo.gl/MjiAms

6. Chandrasekar RSC, Chamlagain B, Kariluoto S, Piironen V, Saris PEJ. Biofortification of riboflavin and folate in idli batter, based on fermented cereal and pulse, by Lactococcus lactis N8 and Saccharomyces boulardii SAA655. J Appl Microbiol. 2017; 122: 1663-1671. Ref.: https://goo.gl/sE3QEG

7. Rani P, Kumar A, Purohit SR, Rao PS. Impact of fermentation and extrusion processing on physicochemical, sensory and bioactive properties of rice-black gram mixed flour. LWT-Food Science and Technology. 2018; 89: 155-163. Ref.: https://goo.gl/BcjcKJ 
8. Venkateshmurthy K, Raghavarao KS. Analysis of modes of heat transfer in baking Indian rice pan cake (Dosa,) a breakfast food. J Food Sci Technol. 2015; 52: 5357-5363. Ref.: https://goo.gl/URh4X2

9. El Sheikha AF. Revolution in Fermented Foods: From Artisan Household Technology to the Era of Biotechnology. Molecular Techniques in Food Biology: Safety, Biotechnology, Authenticity and Traceability. 2018; 241. Ref.: https://goo.gl/6gXVBb

10. Melini F, Melini V, Luziatelli F, Ruzzi M. Current and Forward-Looking Approaches to Technological and Nutritional Improvements of Gluten-Free Bread with Legume Flours: A Critical Review. Comprehensive Reviews in Food Science and Food Safety. 2017; 16: 1101-1122. Ref.: https://goo.gl/z7wQNy

11. Kohajdová Z. Fermented cereal products. In Current Developments in Biotechnology and Bioengineering. 2017; 91-117. Ref.: https://goo.gl/6mkC3L

12. Beniwal $\mathrm{P}$, Jood S. Development, chemical composition and antioxidant activity of dosa prepared using by-products from legume milling industry. Asian J. Dairy \& Food Res. 2015; 34: 247-250. Ref.: https://goo.gl/LuxjWG

13. Narayanan J, Sanjeevi V, Rohini U, Trueman P, Viswanathan V. Postprandial glycaemic response of foxtail millet dosa in comparison to a rice dosa in patients with type 2 diabetes. Indian $\mathrm{J}$ Med Res. 2016; 144: 712-717. Ref.: https://goo.gl/JW4E5X

14. Haripriya A, Mercy L. Development and quality assessment of horse gram based instant dosa mix. ijfn. 2017; 2: 80-84. Ref.: https://goo.gl/cMQHTH

15. Margasahayam A, Balraj Y. Properties of food ingredients during processing in a domestic mixer grinder and subsequent storage: A review. J Food Process Engg. 2018. Ref.: https://goo.gl/6WqCSi

16. Priyanka B, Sudesh J. Development, Chemical Composition and Antioxidant Activity of Dosa Prepared Using Bengal Gram Seed Coat. Int J Adv Nutri Health Sci. 2015; 3: 109. Ref.: https://goo.gl/okLLwp

17. Lin JY, Humbert ES, Sosulki FW. Certain functional properties of sun flower meal products. Journal of Food Science. 1974; 39: 368-370. Ref.: https://goo.gl/fpKNUL

18. Tanaka M, Thanankul D, Lee TC, Chichester CO. A simplified method for the quantitative determination of sucrose, raffinose, and stachyose in legume seeds. J Food Sci. 1975; 93: 665-670. Ref.: https://goo.gl/36J1sc

19. Cohen EH. Association of Official Analytical Chemists. 1917; 54: 212.

20. Kanchana S, Sinkaravadivel A, Alagusundaram K. Standardization of selected ethnic fermented foods and beverages by rationalization of indigenous knowledge, Project submitted by National Agricultural Innovation Project. 2013; 7-8.

21. Saini RS, Sharma, KD, Dhankar OP, Kaushik RA. Laboratory manual of analytical techniques in Horticulture. Agrobios Pub. 2000; 72. Ref.: https://goo.gl/11ppBg

22. Clark J, Cameron Smith, Cori Stevens. Microwavable Pancake Mixes and Methods of Preparing Pancakes. U.S. Patent Application. 2017. Ref.: https://goo.gl/35brjh

23. AOAC. Official method of Analysis, Association of Official Analytical Chemists. USA. 1995.

24. AOAC. Official method of Analysis. Association of Official Analytical Chemists. USA. 1998.

25. AOAC. Official method of Analysis. Association of Official Analytical Chemists. USA. 2005.

26. Istawankiss. Testing methods in food microbiology. Elsevier. 1984; 395-397.

27. Asp NG, Johansson CG, Hallmer H, Silijestom M. Rapid enzymatic assay of insoluble and soluble dietary fibre. J of Agricultural and Food Chemistry. 1983; 31; 476-482. Ref.: https://goo.gl/rdgPmA

28. Gomez KH, Gomez AA. Statistical Procedures for Agricultural Research. 1984; 381. Ref.: https://goo.gl/BCaoZ3

29. Kavitha B, Hemalatha G, Kanchana S, Sundaram SP, Sivasubramaniam K. Physicochemical functional, pasting properties and nutritional composition of selected black gram (Phaseolus mungo L.) varieties. Indian J SciTechnol. 2013; 6: 5386-5394. Ref.: https://goo.gl/B9b54o

30. Muralikrishna G, Bhat UR, Tharanathan RN. Functional characteristics of the mucilaginous polysaccharides derived from Cowpea (Vigna Sinensis), Black Gram (Phaseolus mungo) and Linseed (Linumusitatissimum). Starch/Starke. 1987; 39: 107-109. Ref.: https://goo.gl/PEYUoQ

31. Nazini $P$, Shalini S. Standardization and quality evaluation of idli prepared from pearl millet. Int J Curr Res. 2010; 5: 84-87. Ref.: https://goo.gl/CPBjxv 
32. Asha MR, Susheelamma NS, Bhat KK. Effect of rheological properties of batter and addition of thermally modified rice on quality of vada-a black gram based fried product. $\mathrm{J}$ of Food Science and Technology. 2009; 46: 212-216. Ref.: https://goo.gl/6HEk3q

33. Poongodi Vijayakumar T, Jemima Bery Mohankumar. Quality evaluation of dosa from millet flour blend incorporated composite flour. Elixir Food Science. 2011; 34: 2624-2629. Ref.: https://goo.gl/8LmW33

34. Tharnathan L, Mahadevamma D. Texture analysis of idli. J of Food Science and Technology. 2003; 25: $111-113$.

35. Sanz-Serrano F, Sagues C, Feyissa AH, Adler-Nissen J, Llorente S. Modeling of pancake frying with non-uniform heating source applied to domestic cookers. J Food Engg. 2017; 195: 114-127. Ref.: https://goo.gl/HZcfDD

36. Lu Y, Memon A, Fuerst P, Kizonas A, Morris C, et al. Changes in the phenolic acids composition during pancake preparation: Whole and refined grain flour and processed food classification by UV and NIR spectral fingerprinting method-Proof of concept. J Food Composition and Analysis. 2017; 60: 10-16. Ref.: https://goo.gl/nAXV9Q

37. Alla S. Isolation and characterization of bioactive compounds from black gram and its milled fractions, Project repor. 2010; 2-5.

38. Balasubramanian S, Viswanathan R. Properties of idli batter during its fermentation time. J of Food Processing Preservation. 2007; 31: 32-40. Ref.: https://goo.gl/x6YRn4

39. Lu HZ, Li-Te Li, Wei Cao, Zai-Gui, Tatsumi E. Influence of natural fermentation on physicochemical characteristics of rice noodles. Int J Food Sci Technol. 2003; 38: 505-510. Ref.: https://goo.gl/fbZtNw

40. Reddy CK, Sushellamma NS, Tharanathan RN. Composition and properties of mucilaginous polysaccharide from native and fermented black gram flour. Carbohydrate Polymers. 1990; 12: 189202. Ref.: https://goo.gl/xRYPXZ

41. Sura K, Sarg S, Garg FC. Microbiological and biochemical changes during fermentation of kanji. J Food Sci Technol. 2001; 38: 165-167.

42. Susheelamma NS, Rao MV. Functional role of the arabinogalactan of black gram in the texture of leavened foods (Steamed Puddings). J Food Science. 1979; 44: 1309-1313. Ref.: https://goo.gl/zQwURb 